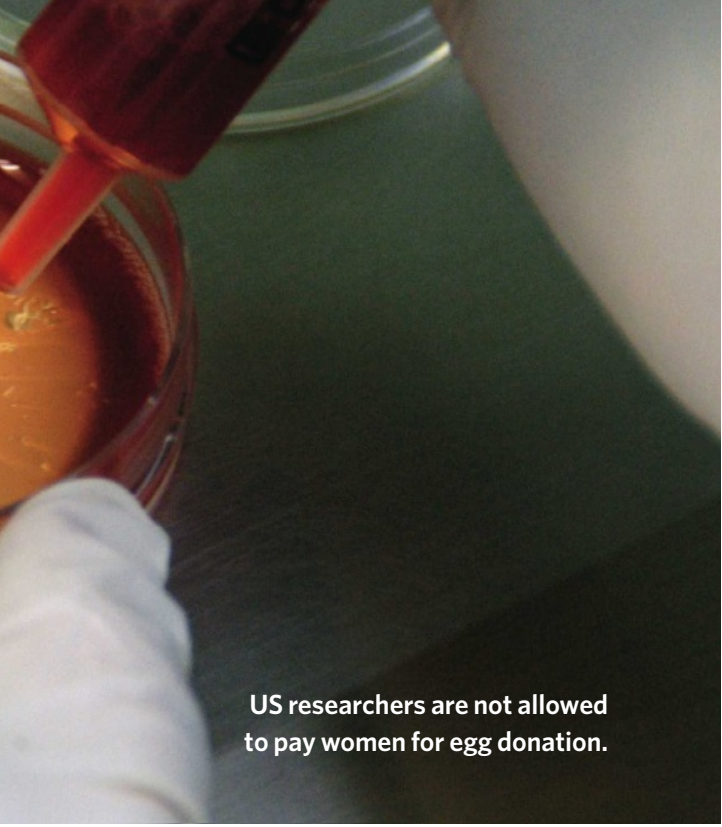

Charo, but it could also provide access to such treatments for more people. Murdoch has so far collected more than 100 eggs in this fashion.

Wood says that this egg-sharing workaround presents a problem; the eggs being used for research are from older individuals, presumably with fertility problems. Using eggs donated by women aged 20-24, he has reportedly achieved cloning success rates near 25\%.

And there are ethical concerns. Marcy Darnovsky of the Center for Genetics and Society in Oakland, California, says that such schemes split the doctor's duty of care three ways: between donor, fertility patient and researchers. And the focus on compensation, she says, distracts from concerns about risks from this one research avenue when other avenues seem open.

Even in light of rapid advancement of induced pluripotent stem cells - embryonic stem cell-like cells created by adding specific genes to adult cells - research using human eggs to reprogramme the nucleus continues, and with some success. Wood says Stemagen's work has been advancing rapidly. Eggan's group, while waiting for fresh eggs, showed that in principle unfertilized eggs could be obviated by introducing a nucleus into an already fertilized egg (D. Egli et al. Nature 447, 679-685; 2007), which might be easier to obtain.

Still, Eggan says, his group's first modest attempts with unfertilized human eggs are more compelling. "Our results confirm, for us, that the best way to do the experiments is with unfertilized oocytes. That said, it doesn't seem like we're going to be getting many of those any time soon."

Brendan Maher

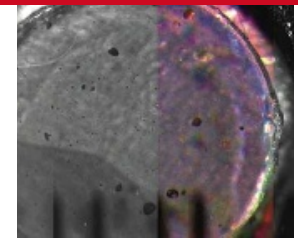

DASTARDLY DANDRUFF

Skin flakes could scupper Phoenix Mars mission.

www.nature.com/news

\section{Fusion reactor faces cost hike}

A massive international nuclear fusion experiment planned for Cadarache, France, is set to cost up to $30 \%$ more than anticipated and be delayed by as much as three years, governments will learn next week.

Construction has not even begun on the ITER fusion reactor, which has been beset by political wrangling since its inception. Now its seven international backers are to be told they will have to come up with an extra $€ 1.2$ billion-1.6 billion (US $\$ 1.9$ billion-2.5 billion) on top of its current $€ 5$-billion construction budget if the project is to be realized.

A report from a group of scientific advisers says the additional money is needed for critical design changes and for coordinating between the participant nations. And the experiment, already delayed, will not be completed until anywhere from one to three years after its current 2016 due date.

Critics expect more cost hikes. "Personally, I think the price will double before it's done," says Stephen Dean, president of Fusion Power Associates, based in Gaithersburg, Maryland.

But ITER officials maintain that the new budget and schedule are achievable and that the review could not have come sooner because the ITER organization was only formed in 2006. "A good, rigorous review could only be done now," says Neil Calder, a spokesman for the project.

ITER is designed to test the feasibility of fusion power. The machine will trap hydrogen isotopes in magnetic fields and heat them to around 100 million Celsius. At that temperature, the hydrogen will fuse to form helium, releasing neutrons and energy in the process. If it works, it a research and educational foundation could lead to a second major source of atomic energy besides fission.

The project was originally proposed as a US-Soviet collaboration in the mid-1980s. It has since added partners including the European Union, South Korea, Japan, China and India, and was redesigned in the late 1990s to make it smaller and cheaper.

When ITER was finalized in mid-2005, its anticipated budget was $€ 10$ billion over 30 years, with half of that going to construction (see Nature 435, 1142; 2005). Dean says that estimate was based on an incomplete design and that "some things were not looked at in detail".

Over the past two years, scientists and engineers have been reworking the design. Researchers now want to add magnets to control a newly discovered instability (see Nature 452, 11; 2008). Buildings at Cadarache will have to be made earthquake-proof, something not included in the original blueprints because the site was undecided. And the addition of latecomers such as India and China will increase its overheads.

The new price tag must be approved by the ITER council, which oversees the project. "For all members, the cost issue is very sensitive," says one Japanese government official familiar with the project. The changes will be presented on 17-18 June at a meeting in Aomori Prefecture in Japan, and a new budget decided at meeting in November.

Dean anticipates that the new budget will ultimately be approved. "This thing has gotten a life of its own - it's almost irrelevant how much it costs or what it's for."

Geoff Brumfiel

See Editorial, page 824

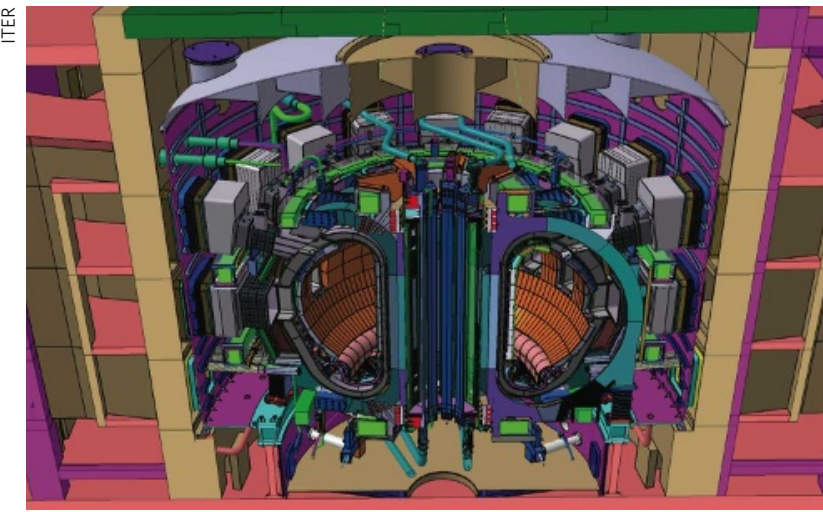

Money to burn: Extra magnets and earthquake protection are some of the factors making ITER more expensive. 